UCRL-ID-118676

\title{
Second Test of Base Hydrolysate Decomposition in a 0.04 Gallon Per Minute Scale Reactor
}

\author{
R. J. Cena \\ C. B. Thorsness \\ T.T. Coburn \\ B.E. Watkins
}

October 11, 1994

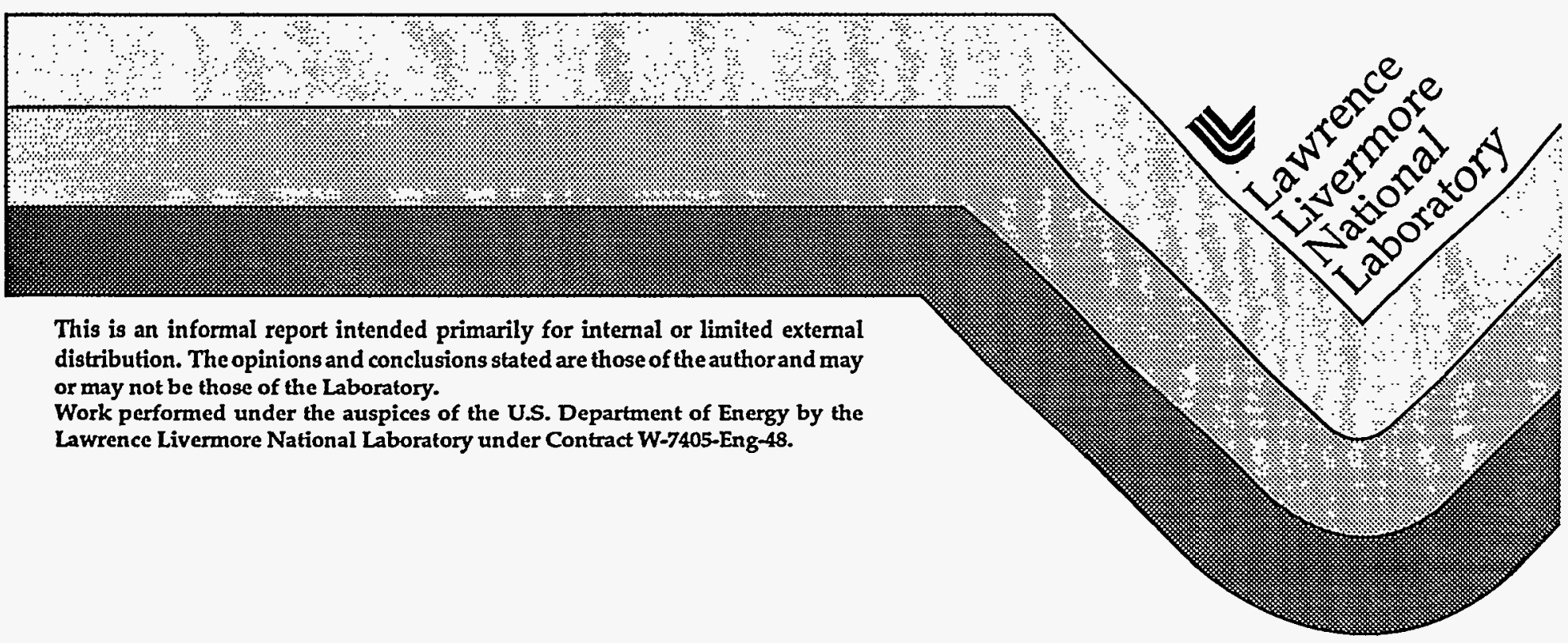

This is an informal report intended primarily for internal or limited external distribution. The opinions and conclusions stated are those of the author and may or may not be those of the Laboratory.

Work performed under the auspices of the U.S. Department of Energy by the Lawrence Livermore National Laboratory under Contract W-7405-Eng-48. 


\section{DISCLAIMER}

This document was prepared as an acccount of work sponsored by an agency of the United States Government. Neither the United States Government nor the University of California nor any of their employees, makes any warranty, express or implied, or assumes any legal liability or responsibility for the accuracy, completeness, or usefulness of any information, apparatus, product, or process disclosed, or represents that its use would not infringe privately own rights. Reference herein to any specific commercial products, process, or service by trade name, trademark, manufacturer, or otherwise, does not necessarily constitute or imply its endorsement, recommendation, or favoring by the United States Government or the University of California. The views and opinions of authors expressed herein do not necessarily state or reflect those of the United States Government or the University of California, and shall not be used for advertising or product endorsement purposes.

This report has been reproduced directly from the best available copy.

Available to DOE and DOE contractors from the Office of Scientific and Technical Information P.O. Box 62, Oak Ridge, TN 37831

Prices available from (615) 576-8401, FTS 626-8401

Available to the public from the National Technical Information Service

U.S. Department of Commerce 5285 Port Royal Rd.,

Springfield, VA 22161 


\section{DISCLAIMER}

Portions of this document may be illegible in electronic image products. Images are produced from the best available original document. 


\title{
Second Test of Base Hydrolysate Decomposition in a 0.04 Gallon Per Minute Scale Reactor
}

\author{
R.J. Cena, C.B. Thorsness, T. T.Coburn, and B.E. Watkins
}

\begin{abstract}
The Lawrence Livermore National Laboratory (LLNL) has built and operated a pilot plant for processing oil shale using recirculating hot solids. This pilot plant, was adapted in 1993 to demonstrate the feasibility of decomposing base hydrolysate, a mixture of sodium nitrite, sodium formate and other constituents. This material is the waste stream from the base hydrolysis process for destruction of energetic materials, being studied by researchers at Los Alamos National Laboratory (LANL). In the Livermore process, the waste feed is thermally treated in a moving packed bed of ceramic spheres, where constituents in the waste decompose, in the presence of carbon dioxide, to form solid sodium carbonate and a suite of gases including: methane, carbon monoxide, oxygen, nitrogen oxides, ammonia and possibly molecular nitrogen. The ceramic spheres are circulated and heated, providing the energy required for thermal decomposition. In addition to being an energy source, the spheres provide a large surface area for evaporation and decomposition to occur, avoiding sticking and agglomeration of the waste while undergoing processing. This is the second test of base hydrolysate destruction in this reactor.
\end{abstract}

We performed a one day ( 2.5 hour) test of the solids recirculation system, with continuous injection of approximately $0.04 \mathrm{gal} / \mathrm{min}$ of waste. Gasses from the packed bed reactor were directed through the lift pipe and water was not condensed. Potassium carbonate $(0.356 \mathrm{M})$ was added to the hydrolysate prior to its introduction to the retort. These two points distinguished this run from the first 1 . Continuous on-line gas analysis was invaluable in tracking the progress of the experiment and quantifying the decomposition products. Analyses showed the primary solid product, collected in the lift exit cyclone, was indeed sodium carbonate, as expected. For the reactor condition studied in this test, $\mathrm{N}_{2} \mathrm{O}$ was found to be the primary nitrogen bearing gas species. In the test, approximately equal quantities of ammonia and nitrogen bearing oxide gases were produced ( $\mathrm{NO}, \mathrm{NO}_{2}$ and $\mathrm{N}_{2} \mathrm{O}$ ). Under proper conditions, this ammonia and $\mathrm{NO}_{x}$ can be recombined downstream to form $\mathrm{N}_{2}$ and $\mathrm{O}_{2}$ as the primary effluent gases. The emissions of nitrogen oxides were not significantly different between the two runs.

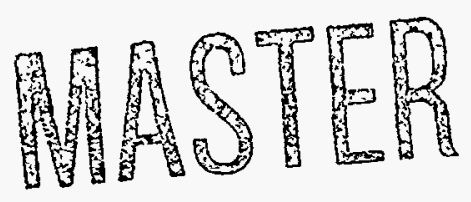

U DISTRIBUTION OF THIS DOCUMENT IS UNLIMITED 


\section{Introduction}

The Lawrence Livermore National Laboratory (LLNL) as part of the Energetic Materials Center, is developing methods for the safe, environmentally sound, destruction of explosives and propellants as a part of the Laboratory's ancillary demilitarization mission. As a result of the ending of the Cold War and the shift in emphasis to a smaller stockpile many weapons, both conventional and nuclear, are scheduled for dismantlement and are being rapidly retired. Energetic materials, both explosives and propellants, from these weapons must either be recycled or safely destroyed. Traditionally, open burn/open detonation has been the method of choice for the destruction of energetic materials. These methods are no longer considered to be environmentally acceptable and we and others are looking for alternative ways to dispose of energetic materials.

The Los Alamos National Laboratory (LANL) has developed a process to demilitarize energetic materials by treatment in boiling aqueous sodium hydroxide. This process is referred to as base hydrolysis and is an excellent way to render these materials non-detonable and non-reactive. However, the base hydrolysis process does produce large volumes hazardous waste that is corrosive and potentially toxic. The base hydrolysate is a mixture of sodium nitrite, sodium formate as well as other, including some unknown, constituents.

Lawrence Livermore National Laboratory has built and operated a pilot plant for processing oil shale using recirculating hot solids. This pilot plant was adapted in the fall and winter of 1993 to demonstrate the feasibility of decomposing base hydrolysate. In the modified LLNL pilot plant, a sample of Los Alamos National Laboratorie's base hydrolysate was thermally treated in a moving packed bed of ceramic spheres, where constituents in the waste decompose, in the presence of carbon dioxide, to form solid sodium carbonate and a suite of gases including: methane, carbon monoxide, oxygen, nitrogen oxides, ammonia and possibly molecular nitrogen. The ceramic spheres are circulated and heated, providing the energy required for thermal decomposition. In addition to being an energy source, the spheres provide a large surface area for evaporation and decomposition to occur, avoiding sticking and agglomeration of the waste while undergoing processing. We performed an extended one day test of the solids recirculation system, with continuous injection of approximately $0.04 \mathrm{gal} / \mathrm{min}$ of waste for a period of 2.5 hours. Solid sodium carbonate, methane, carbon monoxide, nitrogen oxides were the major products.

\section{Pilot Plant Description}

The retort schematic, in Figure 1, shows the configuration of equipment for the waste destruction test. The moving packed bed reactor contains approximately $90 \mathrm{~kg}$ of ceramic spheres with an additional $50 \mathrm{~kg}$ in the waste feed pipe and $55 \mathrm{~kg}$ in 


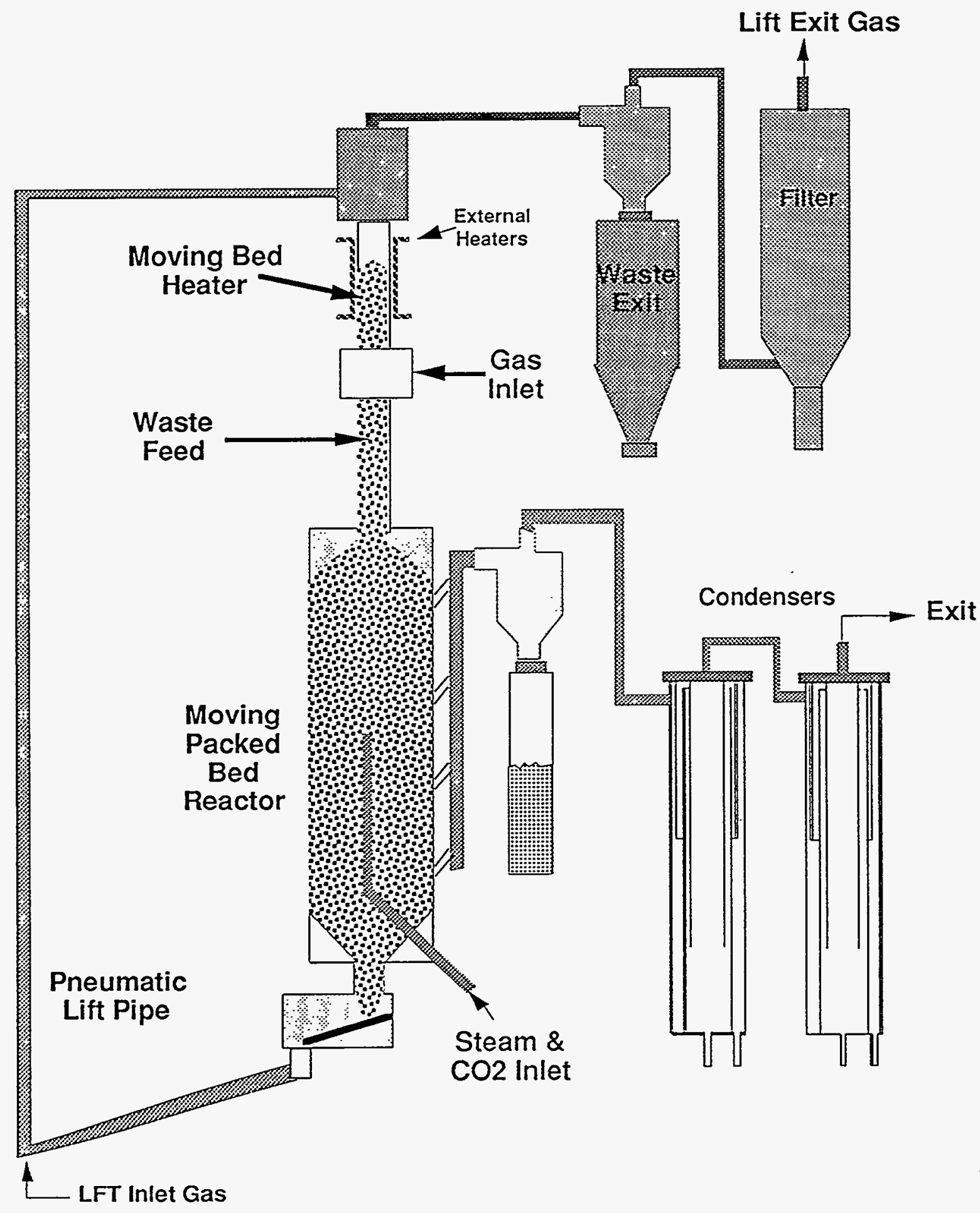

Waste 6

Figure 1. Schematic of Hot-Recycled-Solid Pilot Plant for Demonstration of Base Hydrolysate Destruction 
the moving bed heater. The spheres are circulated and maintained at a temperature at or above $550^{\circ} \mathrm{C}$ to accomplish the decomposition. The spheres are discharged from the reactor at a rate of approximately $10 \mathrm{~kg} / \mathrm{min}$ which gives a solids residence time in the reactor of 9 minutes. A gas actuated L-valve meters the spheres from the reactor to the pneumatic lift pipe. The spheres are lifted to the top of the tower and discharged into a gas/solid separator or classifier. The discharge gas passes though a cyclone separator and sintered metal dust filter and is then vented. The spheres, separated from the gas and dust in the classifier are recirculated back to the reactor after passing through a moving packed bed heater. In the reactor, $\mathrm{CO}_{2}$ is provided as reactants via an injection stinger which dispenses these gases along the centerline. In this test, all produced gas was forced through the reactor to the lift system, exiting with the lift exit gas.

In the previous test ${ }^{1}$ reactor gas was passed through a cyclone and then to a two stage condenser to knock out dust and condensables prior to the gas being vented. No significant products were found in the condensed water during that test.

Heat is picked up by the spheres during circulation. The energy is supplied via electric gas heaters, which preheat gas to $700-800^{\circ} \mathrm{C}$ prior to contacting the spheres and electric heaters strapped to external vessel walls. The combined power input of $8 \mathrm{~kW}$ is enough to evaporate and bring to reaction temperature 0.04 $\mathrm{gal} / \mathrm{min}$ of waste feed.

The primary control of the experiment was to maintain the temperature at the exit of the moving bed reactor at or above $550^{\circ} \mathrm{C}$ by adjustment of the waste injection rate. For the test a waste injection rate of $0.04 \mathrm{gal} / \mathrm{min}$ was achieved. Fgure 3 shows a schematic of the moving bed reactor, with thermocouple positions noted.

\section{Base hydrolysate composition}

PBX 9404 (1 pound of PBX / gal. of base) was disolved in hot $1.5 \mathrm{M}$ sodium hydroxide. The resulting solution $(23 \mathrm{~kg})$ contained $30.49 \mathrm{~g} / \mathrm{L}$ of sodium, $0.89 \mathrm{~g} / \mathrm{L}$ of chloride, $2.88 \mathrm{~g} / \mathrm{L}$ of nitrate and $13.8 \mathrm{~g} / \mathrm{L}$ of nitrite. It showed a pH of 12.83 and a hydroxide concentration of $285 \mathrm{mM}$. It also contained an unknown amount of partial hydrolysis products of the HMX. To this solution was added $0.356 \mathrm{mM}$ potassium carbonate. The purpose of adding the additional carbonate was to buffer the system and make the chemical environment within the reactor more similar to that of LLNL's molten salt process ${ }^{2}$.

\section{Waste Injection Chronology}

The experiment began at 14:00, with waste injection started at 14:08. Progress of the waste injection was followed using bubblers to record the liquid level in the supply vessel. Figure 3 shows the progress of injection during the experiment, except for the first 30 minutes, where the bubbler was off-line. As shown, the injection continued, at a relatively constant rate for the duration of the test, with the the average waste injection rate over this period being $0.04 \mathrm{gal} / \mathrm{min}$. 


\section{Reactor Temperatures}

The temperature exiting the moving bed reactor over the course of the runs is shown in Figure 4. As shown, the reactor temperature was at or above $550^{\circ} \mathrm{C}$ for the entire period of waste injection.

\section{Gas Composition}

The composition of gas species produced during the base hydrolysate decomposition test was monitored online throughout the run. The on-line instruments included a quadrupole mass spectrometer (MS), a fourier transform infrared spectrometer (FTIR), several individual IR meters for $\mathrm{CO}, \mathrm{CO}_{2}$ and $\mathrm{NO}_{x}$ and an $\mathrm{O}_{2}$ analyzer. On-line analysis of gas phase components included: $\mathrm{NO}, \mathrm{NO}_{2}, \mathrm{~N}_{2} \mathrm{O}$, $\mathrm{O}_{2}, \mathrm{CO}, \mathrm{CO}_{2}$ and $\mathrm{H}_{2} \mathrm{O} . \mathrm{N}_{2}$ levels were dominated by the air and $\mathrm{N}_{2}$ used as working fluids for pneumatic lifting, pressure balance and L-valve operation. Therefore, $\mathrm{N}_{2}$ produced from the decomposition of $\mathrm{NaNO}_{2}$ was not detectable. The gas species of primary interest are the oxides of nitrogen, $\mathrm{NO}$ and $\mathrm{NO}_{2}$ and $\mathrm{N}_{2} \mathrm{O}$. The FTIR is capable of quantitatively measuring all three of these species and monitored their evolution in the reactor exit gas throughout the test.

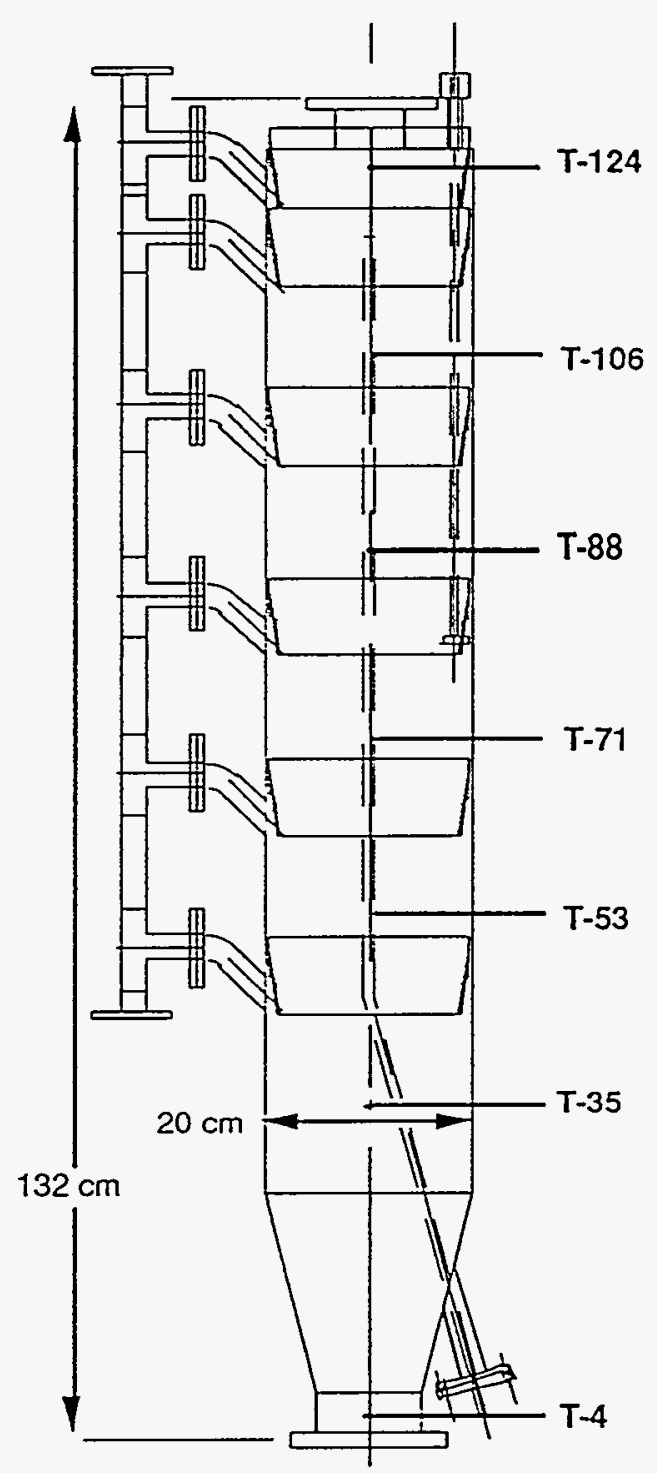

Figure 2. Schematic of Moving Packed Bed Reactor Showing Thermocouple Locations 


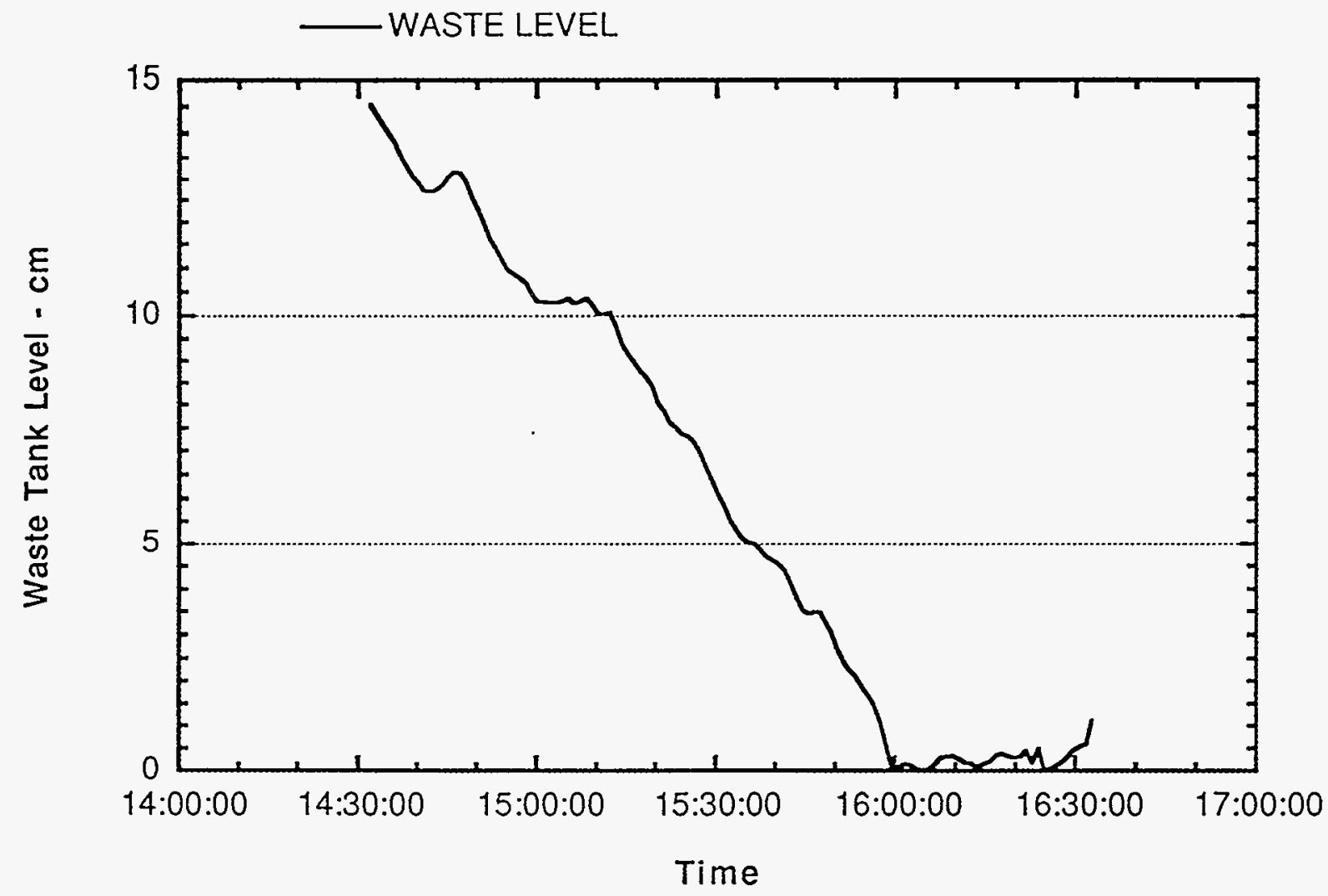

Figure 3. Waste Injection Tank Level During Test

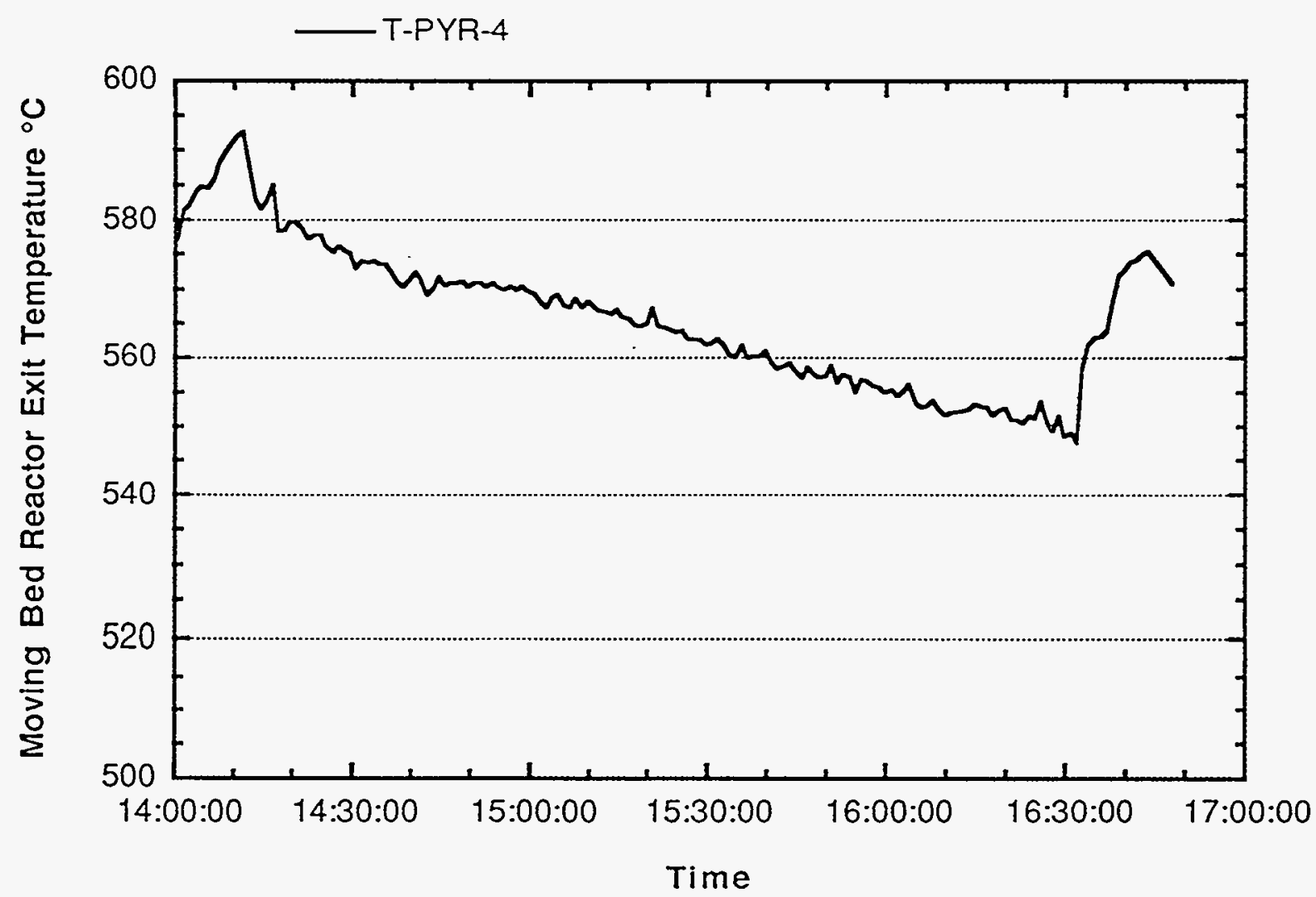

Figure 4. Thermal Response at Bottom of Reactor (T-PYR-4). 
Figure 5 shows the $\mathrm{NO}, \mathrm{NO}_{2}$ and $\mathrm{N}_{2} \mathrm{O}$ production in the lift exit gas during the test as measured by FTIR, in ppm. Figure 6 shows $\mathrm{CH}_{4}$ and $\mathrm{CO}$ concentration in the lift exit gas. Figure 7 shows the three primary lift exit gases, $\mathrm{CO}_{2}, \mathrm{~N}_{2}$ and $\mathrm{O}_{2}$. $\mathrm{CO}_{2}$ was injected into the reactor at a rate of $45 \mathrm{mMol} / \mathrm{s}$. Finally, $\mathrm{H}_{2} \mathrm{O}$ in the lift exit gas is shown in Figure 8.

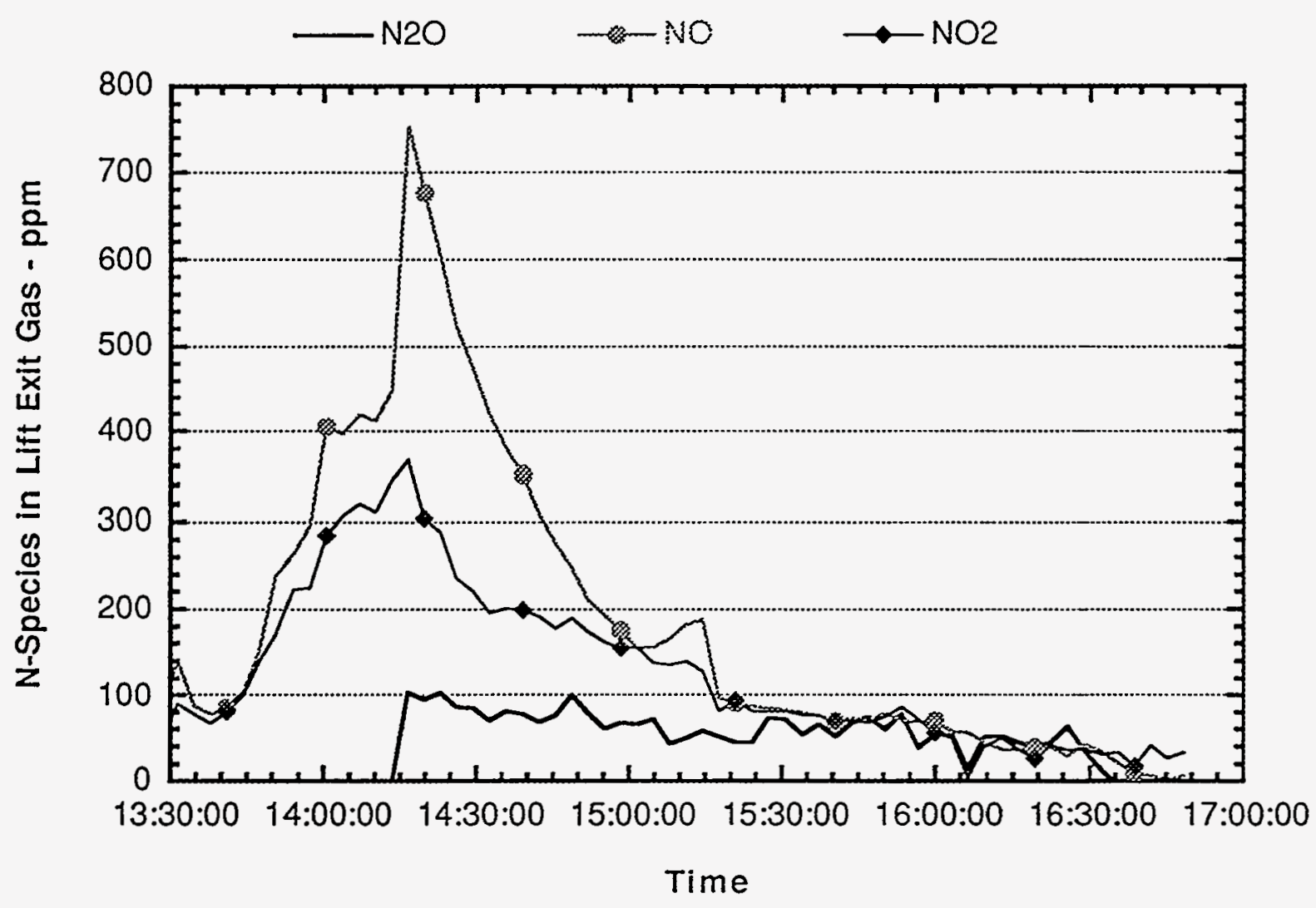

Figure 5. $\mathrm{NO}, \mathrm{NO}_{2}$ and $\mathrm{N}_{2} \mathrm{O}$ in Lift Exit Gas by FTIR Instrument 


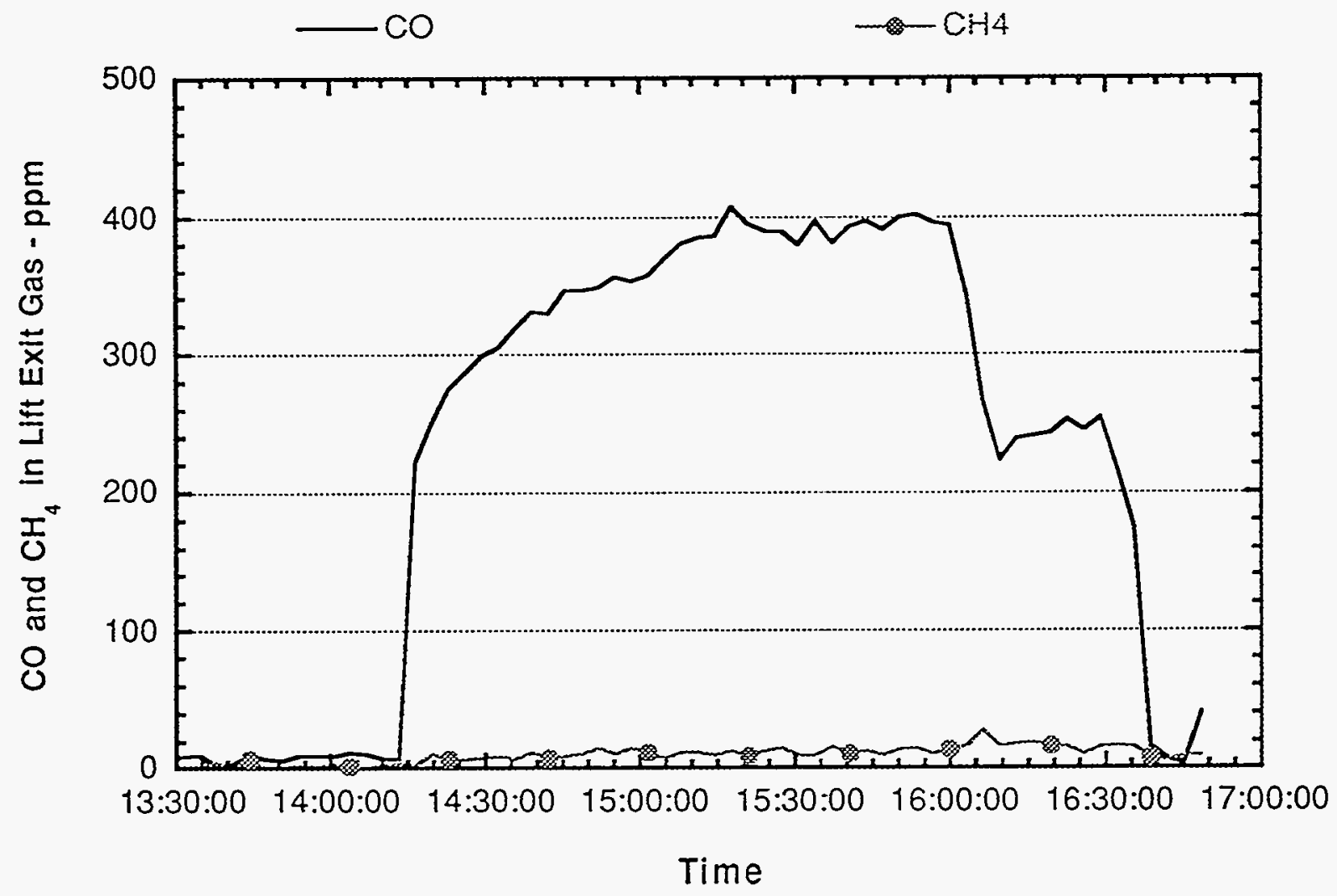

Figure 6. $\mathrm{CO}$ and $\mathrm{CH}_{4}$ in Lift Exit Gas by FTIR Instrument

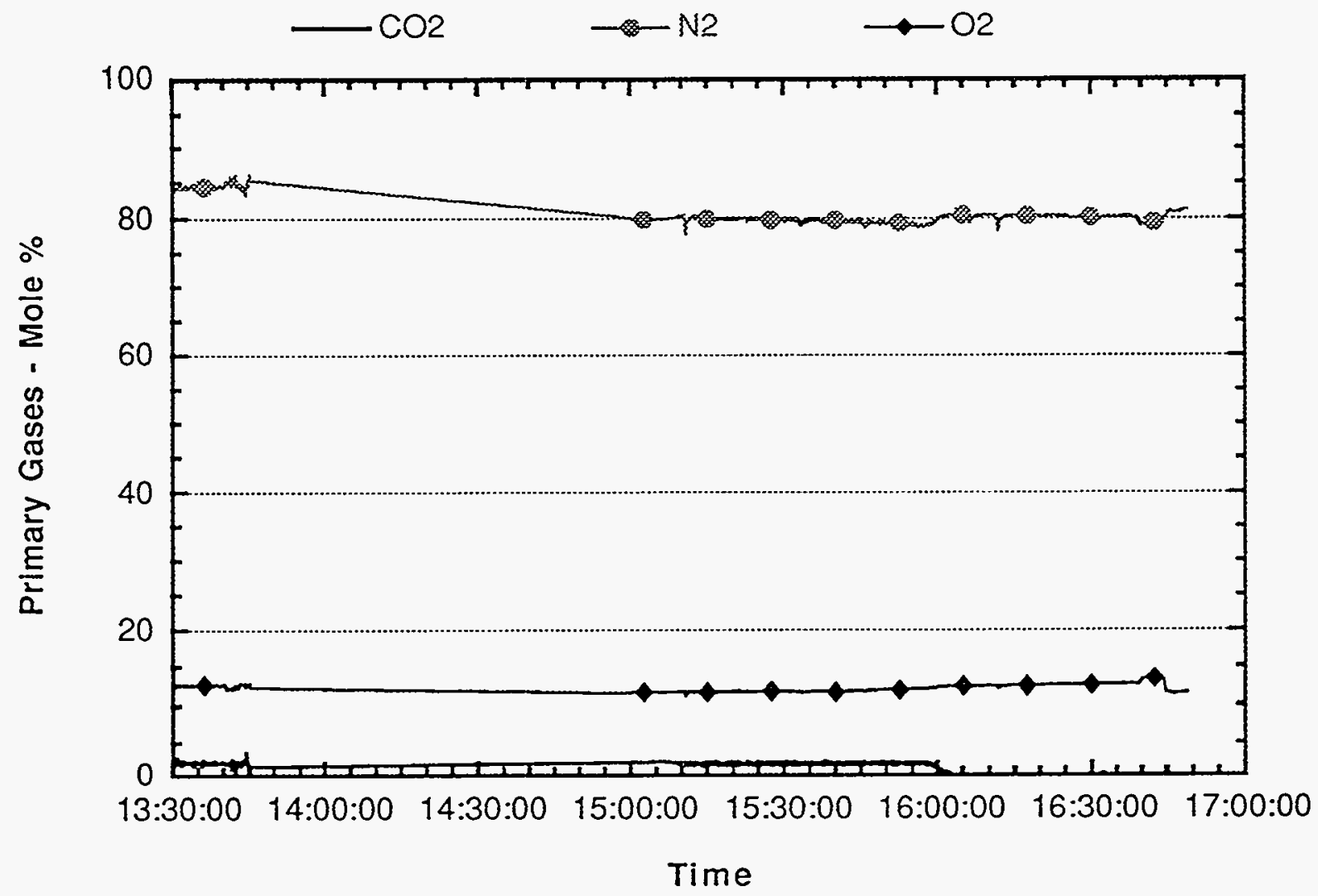

Figure 7. Primary Lift Exit Gases by Mass Spectrometer 


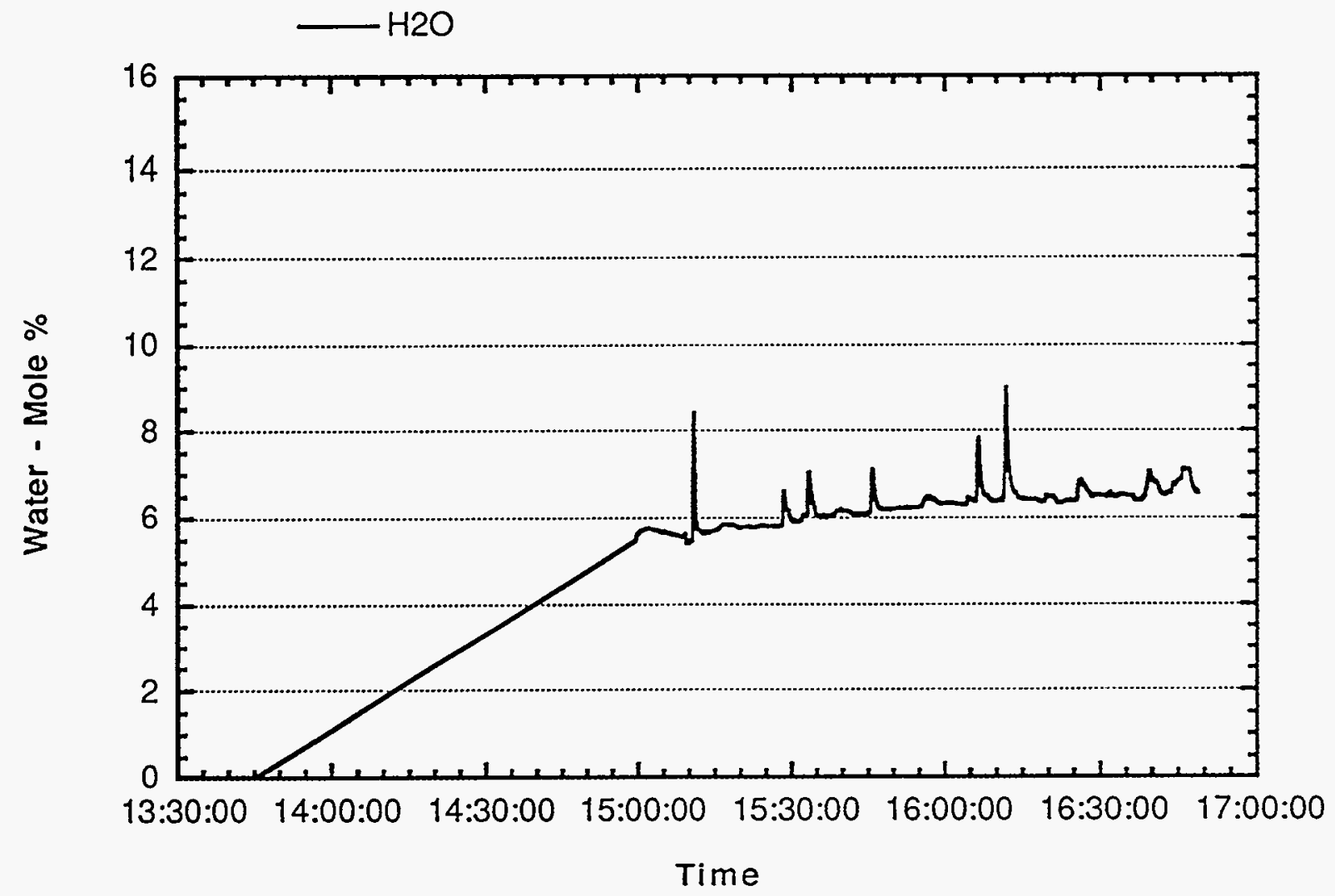

Figure 8. Water in Lift Exit Gas by Mass Spectrometer

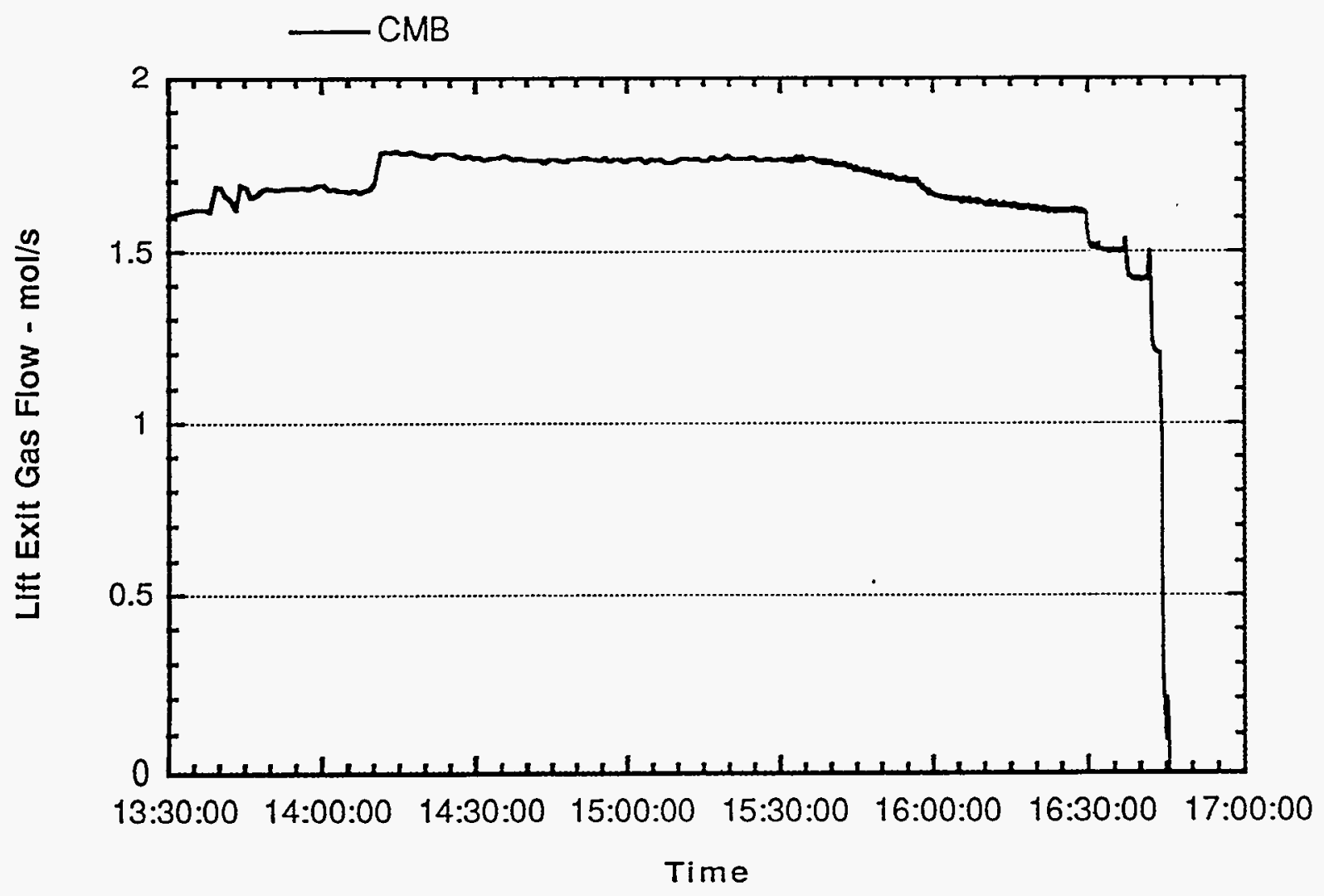

Figure 9. Lift Exit Gas Flow During Experiment 


\section{Post Run Sample Analysis and Balances}

After final shutdown, we began emptying the vessels of the $171 \mathrm{~kg}$ of sphere inventory used. The spheres were removed from the process using the reactor Lvalve and during discharge showed no signs of sticking, tacking of agglomeration. The final inventory of the spheres recovered from the process totaled $170 \mathrm{~kg}$, or no net loss of spheres during processing. During the tests, $23.3 \mathrm{~kg}$ of base hydrolysate solution was injected, containing a total of 98 grams of nitrogen. Table 1 summarizes the atomic balance for nitrogen for the run. In the table, the high initial concentrations of $\mathrm{NO}$ and $\mathrm{NO}_{2}$ are the result of decomposition of nitrate left on the spheres from a previous experiment. $\mathrm{N}_{2} \mathrm{O}$ was the primary nitrogen oxide produced from base hydrolysate decomposition, and accounts for $15 \%$ of the injected nitrogen. To estimate the $\mathrm{NO}$ and $\mathrm{NO}_{2}$ contribution, data from the last 30 minutes of active waste injection was used, corrected for baseline levels, measured following termination of waste injection. Although crude, these values agree pretty well with results of the first base hyrolysate destruction test. The comparison is shown in Table 2.

The total amount of nitrogen produced as nitrogen bearing gases in this test was $23 \%$, compared with $27 \%$ measured in the reactor off-gas in the first test. For that test, an additional amount of $\mathrm{N}_{2} \mathrm{O}$ was speculated to have exited in the lift gas, below the detectable limit. However, based on these results, is appears that this may not be the case. Therefore, during base hydrolysate decomposition, approximately $25 \%$ of the feed nitrogen has been shown to be released as nitrogen bearing gases.

Table 1. Nitrogen Balance

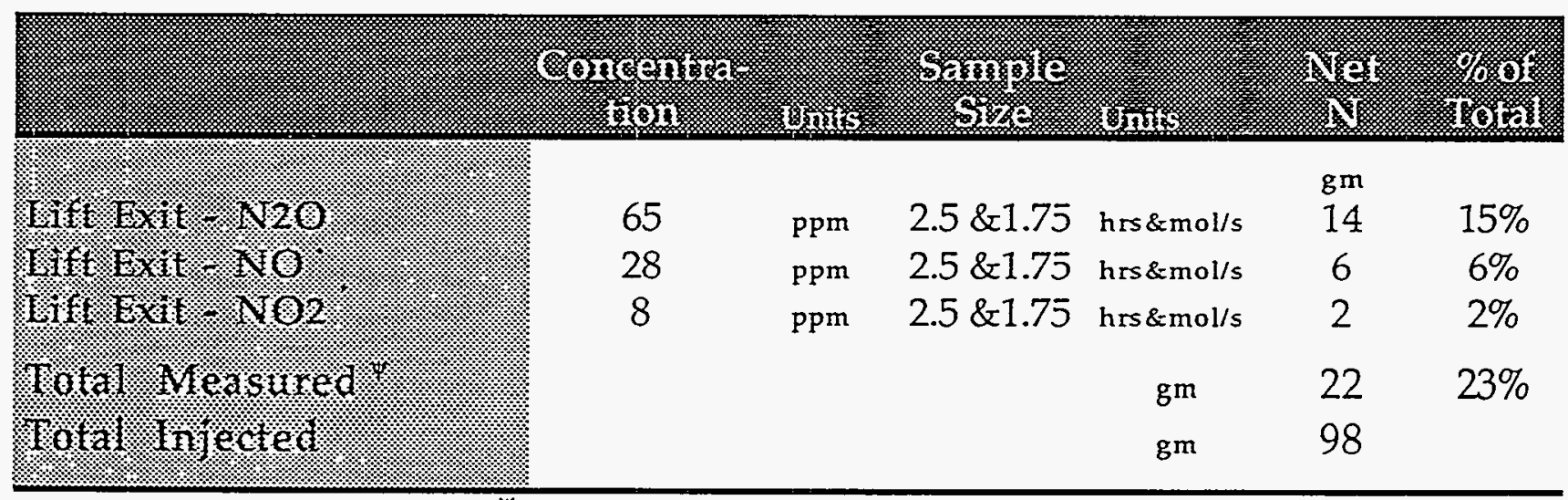

- Data near end of experiment - background $\psi$ Balance is presumed to be Nitrogen 
Table 2. Comparison of N-Species in Exit Gas from Two Tests (Percent of Total Nitrogen Injected)

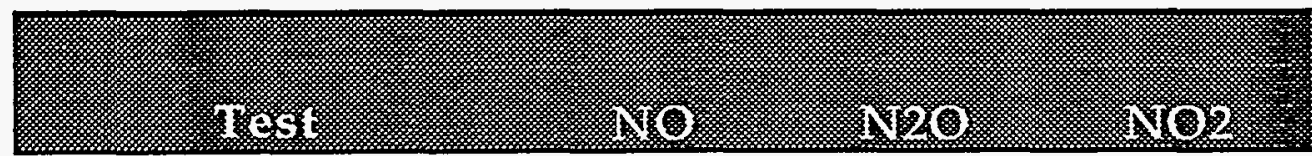

\begin{tabular}{cccc} 
This Test & 6 & 15 & 2 \\
1st Test & 5 & $19-32^{\psi}$ & 3 \\
\hline
\end{tabular}

$\Psi$ Depends on $\mathrm{N} 2 \mathrm{O}$ concentration in Lift

\section{Conclusions}

From the second test of base hydrolysate decomposition, using the HotRecycled-Solid (HRS) pilot plant, the following conclusions are drawn:

- The Hot-Recycle-Solid circulation system operated successfully for 2.5 hours during which $23 \mathrm{~kg}$ of base hydrolysate was processed.

- The primary solid product was sodium carbonate, which is removed from the system as as fine dust, collected in a gas/solid cyclone separator.

- Continuous on-line gas analysis was invaluable in tracking the progress of the experiment and quantifying the decomposition products.

- The analyses showed that $\mathrm{N}_{2} \mathrm{O}$ was the major nitrogen oxide species measured in this test. Other experiments in a more oxidizing environment and longer residence times produces $\mathrm{NO}$ and $\mathrm{NO}_{2}$ as the primary nitrogen oxide species.

- Ammonia production was equivalent to nitrogen oxide production. The ammonia and $\mathrm{NO}_{x}$ could be combined in a downstream reactor producing $\mathrm{N}_{2}$ and $\mathrm{O}_{2}$ as the primary effluent gases.

- Inspection of solids removed from the process following shutdown showed no signs of sticking, tacking or agglomeration.

- Addition of Potassium carbonate to the feed has no effect on emmissions

\section{References}

1. Cena, R.J., Thorsness, C.B., Coburn, T.T. and Watkins, B.E., LLNL Demonstration of Base Hydrolysate Destruction in a 0.1 Gallon Per Minute Scale Reactor, University of California Research Report UCRL-ID-117550.

2. Upadhye, R.S., Watkins, B.E., Pruneda, C.O., and Brummond,, W.A "Molten Salt Destruction as an Alternative to Open Burning of Energetic Material Wastes", presented at the I\&EC Special Symposium, American Chemical Society, Atlanta, Georgia, September 19-21, 1994. 